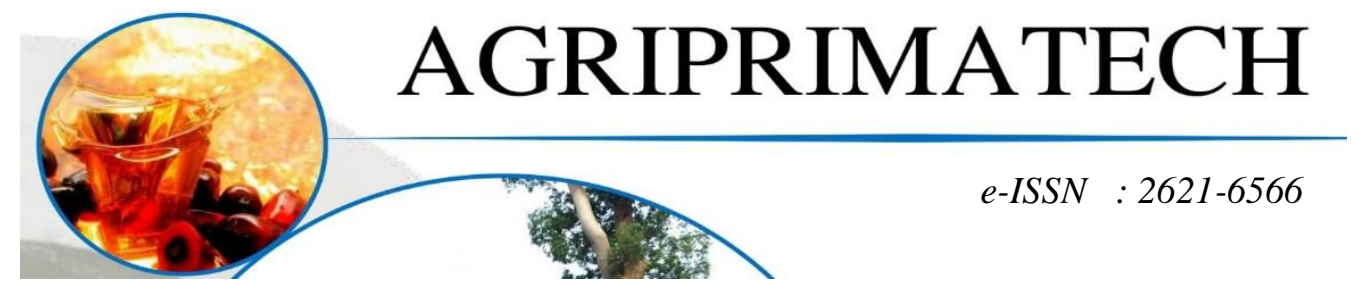

\title{
ANALISIS FAKTOR YANG MEMPENGARUHI KONSUMEN DALAM PENGAMBILAN KEPUTUSAN PEMBELIAN MINYAK GORENG CURAH
}

\author{
SRI DELIMA ${ }^{1}$, MYRNA PRATIWI NASUTION² \\ ${ }^{1}$ Mahasiswa Fakultas Agroteknologi, Universitas Prima Indonesia, Sumatera Utara \\ ${ }^{2}$ Dosen Fakultas Agroteknologi, Universitas Prima Indonesia, Sumatera Utara \\ Email: Sridelima1506@Gmail.com
}

\begin{abstract}
ABSTRAK
Penelitian ini bertujuan untuk mengidentifikasi karakteristik konsumen minyak goreng curah dilokasi penelitian,mengidentifikasi proses pengambilan keputusan konsumen dalam membeli produk minyak goreng curah dan untuk mengetahui faktor-faktor yang berpengaruh terhadap keputusan konsumen dalam pembelian produk minyak goreng curah.pengambilan sampel dilakukan dengan menggunakan teknik purposive sampling dengan sampel sebanyak 100 responden. Metode analisis yang digunakan adalah metode analisis deskriptif, analisis faktor Pengelolahan data dibantu oleh microsoft excel 2013 dan statistical package social science (SPSS) versi 21. Penelitian ini dilakukan pada bulan Maret-April 2020. Hasil penelitian ini dapat disimpulkan bahwa (1) konsumen minyak goreng curah didominasi oleh usia 31-40 tahun (67\%), sebagian besar memiliki latar pendidikan SMP (73\%), klarifikasi pekerjaan konsumen rata-rata ibu rumah tangga (100\%).(2) proses pengambilan keputusan pembelian konsumen minyak goreng curah melalui lima tahap proses yaitu: pengenalan masalah, pencarian informasi, evaluasi alternatif, keputusan pembelian, perilaku paska pembelian; (3) Hasil dari analisis faktor bahwa 7 faktor tersebut adalah culture factor, social factor, pesonal culture social factor, social psikologis factor, psikologis factor, culture factor, culture psikologis factor.
\end{abstract}

Kata Kunci: Analisis, Faktor, Keputusan, Konsumen.

\section{PENDAHULUAN}

Minyak goreng adalah salah satu bahan yang termasuk dalam sembilan bahan pokok yang cukup penting yang berasal dari lemak, baik yang berasal dari lemak tumbuhan maupun dari lemak hewan yang dimurnikan dan minyak goreng juga sangat penting sebagai pengantar panas, penambah rasa gurih pada makanan sehingga konsumen menikmati makanan tersebut.(Abidanish,2010)

Minyak goreng terbagi menjadi dua yaitu minyak goreng kemasan bermerek dan minyak goreng curah, minyak goreng kemasan bermerek merupakan minyak 
goreng yang dikemas menggunakan kemasan khusus yang diberi label dan mengandung vitamin $A$ dan $E$ sehingga bukan hanya menyehatkan tetapi juga membantu mengatasi berbagai penyakit termaksuk kanker.

Minyak goreng kemasan proses penyaringan nya dilakukan dua hingga tiga kali sedangkan minyak goreng curah adalah produk turunan minyak kelapa sawit namun minyak ini tidak murni seperti minyak goreng dalam kemasan bermerek karena minyak goreng curah hanya melalui tahap pemurnian, pemutihan, dan penghilangan bau dan penyaringan nya hanya dilakukan sekali dan biasanya minyak goreng ini dikemas dengan menggunakan drum dan distribusikan menggunakan mobil tangki ke berbagai pelosok negeri, karena dari segi ekonomi yang menurun dan pekerjaan yang tidak mendukung sehingga masyarakat di desa pantai cermin lebih memilih membeli minyak goreng curah karena harga yang murah dan terjangkau bagi masyarakat yang menggunakan minyak tersebut.(Dewi, 2012)

\section{METODE PENELITIAN}

Penelitian ini dilakukan di desa pantai cermin kanan, kecamatan pantai cermin kabupaten serdang bedagai dan dilakukan di ibu rumah tangga yang selalu memakai minyak goreng curah. Penelitian ini dilakukan dibulan april sampai mei tahun 2020.

Data yang dilakukan dalam penelitian adalah data primer dan data skunder. Menurut Sugiyono (2013) data primer adalah pengumpulan data yang dapat dilakukan dengan cara wawancara langsung seperti memberikan kuesioner kepada konsumen

\section{HASIL DAN PEMBAHASAN}

\section{Gambaran Umum Lokasi Penelitian}

Responden dalam penelitian ini adalah ibu rumah tangga yang mengkonsumsi minyak goreng curah dikecamatan pantai cermin dan lain-lain. Data sekunder adalah pengumpulan data dengan cara tidak langsung seperti pencarian melalui internet,buku,dan lain-lain. Data sekunder antara lain adalah data lembaga lain seperti badan pusat statistik (BPS) pantai cermin.

Badan pusat statistik kabupaten serdang bedagai menyebutkan bahwa jumlah ibu rumah tangga didesa pantai cermin kanan pada tahun 2018 sebesar 4151 ibu rumah tangga kepadatan jiwa 1022 jiwa $/ \mathrm{km}^{2}$ orang. Dalam penelitian ini jumlah yang ditentukan oleh penelitian sebesar 100 responden. Responden dalam penelitian ini adalah ibu rumah tangga yang mengonsumsi minyak goreng curah, jumlah sampel yang digunakan untuk menentukan ukuran minimal sampel yang di butuhkan dari suatu populasi adapun rumusnya sebagai berikut:

Dimana:

$$
n=\frac{N}{1+\epsilon^{2} N}
$$

$\mathrm{n}=$ besar sampel

$\mathrm{N}=$ besar populasi

$\epsilon=$ batas toleransi kesalahan (error tolerance) $10 \%$

$$
\begin{gathered}
n=\frac{4151}{1+4151(0,01)^{2}} \\
n=\frac{4151}{42,51} \\
=97,6 \text { orang }
\end{gathered}
$$

Dalam penelitian ini jumlah yang ditentukan oleh penelitian sebesar 100 responden. Data jumlah populasi ketika melakukan penelitian dapat ilihat dari rumus yang di ambil berdasarkan sample dari kecamatan pantai cermin kabupaten serdang bedagai.

kabupaten serdang bedagai. Penelitian ini mengambil sebanyak 100 responden,

karakteristik umum konsumen pada penelitian ini dibedakan dari usia, keluarga, 
peran dan status, kelompok referensi, pekerjaan,kepribadian,gaya hidup dan keinginan diri sendiri.

Konsumen minyak goreng tidak bermerek/curah mayoritas yang banyak mengkonsumsi oleh usia 31-40 tahun sebesar $67 \%$. Konsumen dengan usia 31-40 tahun merupakan konsumen yang melihat harga minyak goreng curah yang murah sehingga sesuai dengan pendapatan, dan minyak goreng curah juga dapat dibeli dengan jumlah yang sedikit.minyak goreng curah juga banyak mengandung asam lemak,( asam lemak jenuh :miristat 1-55\%, palmitat $5-15 \%$, strearat $5-10 \%$, asam lemak tak jenuh: oleat $70-80 \%$, linoeat $3-11 \%$, palmitoleat $0,8-1,4 \%$ ), (Kataren,2005) selanjutnya $20 \%$ responden berusia 41-50 tahun, $11 \%$ responden berusia $21-30$ tahun dan $2 \%$ responden berusia $>50$ tahun. Mayoritas konsumen latar belakang pendidikan SMP sebanyak $73 \%$, SD sebesar $15 \%$, tidak sekolah sebesar $11 \%$,dari data tersebut diketahui bahwa konsumen minyak goreng curah terbanyak yang mengkonsumsi yaitu yang berpendidikan SMP, Berdasarkan hasil pengelolahan data yang diperoleh dari kuesioner diketahui bahwa responden memiliki klarifikasi pekerjaan yaitu ibu rumah tangga 100\% .

\section{Proses Pengambilan Keputusan Pembelian Konsumen}

Proses membeli suatu produk atau jasa yang dilakukan konsumen secara konsisten dan bijaksana yang dilakukan untuk memenuhi kebutuhan. Yang meliputi pengenalan masalah, pencarian informasi, evaluasi alternatif, keputusan pembelian dan prilaku paska pembelian.

Pengenalan masalah adalah tahap awal ketika seseorang sedang melakukan penelitian, pencarian serta penggunaan produk demi memenuhi kebutuhan seseorang. Berdasarkan hasil penelitian yang dilakukan oleh 100 responden maka diketahui sebagian besar alasan konsumen membeli minyak goreng curah adalah karena 50\% murah dan 50\% harga juga terjangkau.Hasil tersebut menunjukkan bahwa harga sangat berpengaruh terhadap pembelian minyak goreng curah tersebut. Setelah mengetahui permasalahan yang dialami, maka seorang konsumen akan melakukan pencarian informasi terhadap kebutuhan mereka. Informasi yang mereka dapat akan memutuskan mereka dalam pemilihan proses pembelian. Berdasarkan dari hasil responden maka dapat diketahui bahwa suatu pencarian informasi suatu produk minyak goreng curah $100 \%$ dari penjual. Dalam hal ini responden ketika melakukan pembelian minyak goreng kebanyakan yang di jual diwarung adalah minyak goreng curah.Setelah konsumen mendapatkan banyak infomasi mengenai suatu produk yang akan di gunakan oleh konsumen, maka di evaluasi alternatif ini konsumen akan mengetahui bahwa memilih suatu produk yang sesuai dengan kebutuhan konsumen. Setelah itu konsumen memilih berbagai macam produk yang akan dibandingkan dengan kriteria mereka. Setelah melakukan banyak pertimbangan mengenai suatu produk dalam proses evaluasi alternatif,proses selanjutnya adalah keputusan pembelian konsumen. harga $100 \%$ menjadi paling utama yang dilihat oleh konsumen dalam proses pembelian minyak goreng curah karena konsumen tersebut tidak memperhatikan produk yang terpenting mereka dapat membeli minyak goreng curah untuk kebutuhan mereka. pembelian minyak goreng curah 100\% dilakukan konsumen setiap hari. pembelian $98 \%$ lebih banyak dalam bentuk plastik dan $2 \%$ pembelian dalam bentuk botol, $52 \%$ konsumen membeli minyak goreng curah sebanyak $1 / 4 \mathrm{~kg}$ dan $31 \%$ konsumen membeli minyak goreng curah sebanyak $1 / 2 \mathrm{~kg}$ sedangkan $1 \mathrm{~kg}$ konsumen membeli minyak goreng curah sebanyak $17 \%$. konsumen membeli minyak goreng curah $100 \%$ diwarung. tingkat kepuasan konsumen $100 \%$ sangat puas dalam membeli minyak goreng curah.

setelah keputusan pembelian konsumen maka konsumen tersebut akan melakukan 
Agriprimatech

Vol. 4 No. 1, Oktober 2020

penilaian tersendiri terhadap produk yang mereka gunakan.konsumen yang merasa puas terhadap produk sudah memenuhi kebutuhan mereka, dan akan terdorong untuk melakukan pembelian ulang.

konsumen tersebut 100\% akan mencari kewarung lain.hal tersebut karena mereka memikirkan pendapatan ekonomi mereka yang kurang.

\section{Analisis Faktor}

$\begin{array}{crr}\text { Tindakan } & \text { konsumen secara } \\ \text { langsung terlibat } & \text { didalam usaha }\end{array}$ menggunakan produk barang dan jasa dalam proses pengambilan keputusan yang mengikuti tindakan-tindakan tersebut.adapun faktor-faktor yang mempengaruhi perilaku konsumen yaitu faktor budaya, faktor sosial, faktor pribadi, faktor psikologis. Untuk dapat mengetahui faktor mana yang berpengaruh terhadap keputusan konsumen maka digunakan alat analisis faktor. Pada Analisis faktor dipakai untuk memperkecil jumlah variabel dan membentuk menjadi lebih sedikit dan menamakannya sebagai faktor.kemudian alat analisis faktor juga sebagai perangkat prosedur penelitian dalam melakukan sejumlah item untuk menentukan apakah item tersebut saling terkait atau tidak.

Adapun kriteria signifikannya adalah angka > 0,05 maka $\mathrm{HO}$ diterima angka sig pengujian korelasi antar variabel diukur dengan menggunakan keiser mayer olkin (KMO) dan measure of sampling adequaciye (MSA). KMO adalah indek perbandingan besar koefisien korelasi pengamatan dengan besarnya koefisien korelasi persial. Angka KMO yang semakin mendekati satu menunjukkan kesesuaian penggunaan analisis faktor. Hasil pengujian korelasi pada penelitian ini memperlihatkan korelasi angka KMO sebesar 0,692 dengan signifikan sebesar 0,000. Angka KMO 0,692 menunjukkan bahwa penggunaan analisis faktor cukup sesuai dan nilai signifikannya jauh dibawah 0,05 $(0,00<0,05)$ menunjukkan
e-ISSN :2621-6566

bahwa variabel sudah memadai untuk dianalisis lebih lanjut.

Kemudian dilakukan proses

penyaringan pada sejumlah variabel tersebut, sehingga didapat variabel yang memenuhi syarat untuk dianalisis. Angka MSA berada diantara nol sampai satu. Nilai MSA sebesar satu, maka variabel tersebut dapat diprediksi tanpa kesalahan oleh variabel lain. Nilai MSA dapat dilihat pada tabel anti image matrics yaitu sejumlah angka yang terbentuk diagonal bertanda "a" pada bagian anti image matrics. Pada pengelolahan data ternyata dari 20 variabel yang diteliti 20 variabel semua dapat diteliti yang memiliki nilai MSA lebih dari 0,5 sehingga variabel telah memenuhi syarat untuk dianalisa lebih lanjut.

Kemudian melakukan proses inti dari analisa faktor yakni mengektrasi sekumpulan variabel yang ada, sehingga terbentuk satu atau lebih faktor. Metode yang digunakan dalam proses ekstaksi adalah analisis komponen utama (princical analysis). Dalam hal ini seberapa besar masing-masing variabel dapat menjelaskan faktor yang terbentuk dapat diketahui dari niat komunalitas variabel tersebut. Komunalitas pada dasarnya adalah jumlah ragam dari suatu berubah mula-mula yang dapat dijelaskan oleh faktor-faktor yang ada. Semakin besarnya nilai komunitas sebuah variabel berarti semakin erat hubungannya dengan faktor yang terbentuk.

Dari pengelolahan nya ada 7 faktor yang dapat mempengaruhi pengambilan keputusan pembelian konsumen. Pembentukkan faktor-faktor ini terdapat pada tabel total variance explained yang terlihat ketujuh faktor yang terbentuk ini memiliki nilai angka eigenvalue diatas satu. Nilai angka eigenvalue menunjukkan kepentingan relatif masing-masing faktor dalam menghitung varian seluruh variabel yang dianalisis. Nilai eigenvalue dibawah satu tidak digunakan dalam menghitung faktor yang terbentuk.

Proses analisis berikutnya dilakukan pada tabel rotated component 
Agriprimatech

matrix yang menunjukkan perdistribusian 20 variabel kedalam 7 faktor yang terbentuk. Angka-angka pada tabel component matrix memperlihatkan nilai loading factor yang menunjukkan nilai korelasi antara suatu variabel dengan 7 faktor terbentuk.

Berdasarkan hasil yang diperoleh tabel tersebut maka dilakukan perbandingan besar korelasi dari nilai loading factor guna menentukan variabel tersebut termaksuk ke dalam faktor yang mana. Namun data pada tabel rotated component matrix masih terdapat beberapa variabel yang tidak dapat terlihat perbedaan secara nyata pada nilai loading factomya, sehingga sulit dalam menentukan variabel-variabel yang diteliti termasuk ke dalam faktor yang mana. Hal ini terlihat dari nilai loading factor yang masih dibawah 0,5 adapun syarat variabel yang termasuk kedalam sebuah faktor yang terbentuk adalah nilai loading factor harus di atas 0,5 .
Kemudian dilakukan proses rotasi dengan metode varimax untuk memperjelas posisi variabel dalam setiap faktor. Hasil dari proses ini tidak merubah jumlah faktor yang telah terbentuk, tetapi hanya merubah nilai loading factor nya saja. Dan agar terlihat jelas perbedaan dengan membesarkan nilai loading factor yang memang awalnya sudah besar dan begitu sebaliknya mengecilkan nilai loading factor yang memang sudah kecil, sehingga terlihat perbedaan nyata. Berdasarkan hasil pada tabel rotated component matrix setiap variabel yang terdapat pada faktor yang terbentuk tersebut maka harus memenuhi ketentuan cut off point dimana nilai loading faktornya harus lebih besar 0,5 agar variabel tersebut dapat secara nyata termaksuk ke dalam bagian dari suatu faktor. hasil analisis faktor dari variabel-variabel yang telah diolah dan terbentuk menjadi 7 faktor. (1) pesonal Factor Varian 23,165\%,(2) social factors Varian 13,532 \%,(3) Pesonal culture social factor Varian 8,567\%,(4) Social fsikologis factor Varian 6,647\%,(5)Psikologis factor Varian 5,957 \%,(6) culture factor Varian $5,715 \%,(7)$ culture psikologis factor Varian $5,488 \%$.

\section{KESIMPULAN}

1. Berdasarkan hasil penelitian dapat diketahui sebagian besar dari konsumen memiliki kelompok usia 3140 tahun. Tingkat pendidikan sebagian besar SMP/ Sederajat, klarifikasi pekerjaan adalah ibu rumah tangga.serta di variabel pembelian berpengaruh signifikan terhadap keputusan konsumen dalam membeli minyak goreng curah di kecamatan pantai cermin.

2. Proses yang dilakukan konsumen dalam membeli minyak goreng curah berdasarkan alasan utama karena harga yang murah, dan sumber informasi yang didapat yaitu dari penjual serta konsumen juga merasa sangat 
puas dalam membeli produk minyak goreng curah.

3. Berdasarkan dari analisis faktor didapat bahwa terbentuk tujuh faktor yang mempengaruhi keputusan konsumen dalam membeli minyak goreng curah ke tujuh faktor tersebut adalah culture factor, social factor, personal culture social factor, social psikologis factor, psikologis factor, culture factor, culture psikologis factor. Faktor Yang sangat mempengaruhi dalam keputusan konsumen membeli minyak goreng curah adalah faktor culture ,sosial, personal faktor.

\section{Saran}

Berdasarkan penelitian, maka penulis dapat memberikan saran sebagai berikut:

1. Kepada pedagang serta penjual minyak goreng curah hendak nya memperhatikan tingkat kenyamanan konsumen pada saat berbelanja di warung tersebut.

2. Kepada konsumen khusus ibu-ibu rumah tangga agar ketika pendapatan konsumen meningkat sebaik nya membeli minyak goreng bermerek daripada minyak goreng curah dikarenakan dari segi kualitas dan higienitas minyak goreng curah tidak sebaik minyak goreng bermerek

3. Kepada pemerintah hendak nya lebih stabil terhadap harga minyak goreng curah yang cendrung berubah-ubah.

4. Kepada penelitian yang selanjutnya disarankan untuk melakukan penelitian mengenai loyalitas dan strategi pemasaran terhadap minyak goreng curah.

\section{DAFTAR PUSTAKA}

Abidanish, 2010. Teknik Pintar Membuat Minyak Kelapa.Http://Produk Kelapa.Wordpress.Com/2010/02/16/ Teknik-Pintar-Membuat-

Minyak-Kelapa/.(Diakses Pada Tanggal 20 Februari 2016.

[BPS] Badan Pusat Statistik Kab.Serdang Bedagai.Penduduk, Rumah Tangga Dan Rata-Rata Anggota Rumah Tangga Tahun 2018.

Dewi Mt, Hidajati N 2012. Peningkatan Mutu Minyak Goreng Curah Menggunakan Absorben Bentonit Teraktivasi. Jurnal Kimia UNESA, 1(2):47-52.

Sugiyono,2013. Metode Penelitian Bisnis.Bandung:Alfabeta. 